\title{
PEMANFAATAN LIMBAH USUS AYAM SEBAGAI BAHAN BAKU PAKAN IKAN LELE DI DESA KARANG ENDAH, KECAMATAN GELUMBANG, KABUPATEN MUARA ENIM
}

\section{UTILIZATION OF POULTRY OFFAL MEAL AS RAW MATERIAL FOR CATFISH FEED IN KARANG ENDAH VILLAGE, GELUMBANG DISTRICT, MUARA ENIM REGENCY}

\author{
Mohamad Amin*, Dade Jubaedah, Yulisman, Retno Cahya Mukti, Ade Dwi Sasanti, \\ Muhammad Aulia Amri
}

Program Studi Budidaya Perairan, Fakultas Pertanian, Universitas Sriwijaya

*email: amin.unsri@gmail.com

\begin{abstract}
ABSTRAK
Permasalahan yang sering dialami oleh pembudidaya ikan termasuk yang dihadapi oleh kelompok pembudidaya ikan di desa Karang Endah adalah tingginya harga pakan komersil sehingga menyebabkan biaya poduksi semakin tinggi. Tujuan dari kegiatan ini adalah mengevaluasi pemanfaatan limbah usus ayam sebagai bahan baku pakan ikan lele di desa Karang Endah, Kecamatan Gelumbang, Kabupaten Muara Enim, Sumatera Selatan. Metode yang digunakan melalui sosialisai dan diskusi serta tanya jawab, pelatihan praktek pembuatan pakan serta pendampingan demplot pemanfaatan limbah usus ayam sebagai bahan baku pakan ikan lele. Kegiatan pengabdian kepada masyarakat (PKM) yang dilakukan terlaksana dengan lancar. Pembudidaya dapat membuat pakan dengan memanfaatkan limbah usus ayam dan mengaplikasikan pakan dalam kegiatan budidaya ikan lele.
\end{abstract}

Kata kunci: Ikan lele, Pakan, Usus Ayam, Desa Karang Endah

\section{ABSTRACT}

Problems that are often experienced by fish farmers including those faced by groups of fish farmers in the village of Karang Endah are the high price of commercial feed, causing higher production costs. The purpose of this activity is to evaluate the utilization of chicken intestine waste as raw material for catfish feed in Karang Endah village, Gelumbang District, Muara Enim Regency, South Sumatra. The method used is through socialization and discussion as well as questions and answers, training in the practice of making feed and assisting with the demonstration plot of utilizing chicken intestine waste as raw material for catfish feed. Community service activities (PKM) carried out smoothly. Cultivators can make feed by utilizing chicken intestine waste and applying feed in catfish farming activities.

Keywords: Catfish, Feed, Poultry offal meal, Karang Endah Village

PENDAHULUAN

Permasalahan yang sering dialami oleh pembudidaya ikan termasuk yang dihadapi oleh kelompok pembudidaya ikan di desa Karang Endah adalah tingginya harga pakan komersil sehingga menyebabkan biaya poduksi semakin tinggi. Sekitar $60-70 \%$ biaya produksi kegiatan budidaya berasal dari pakan [1]. Oleh karena itu, perlu dilakukan pembuatan pakan ikan menggunakan bahan baku lokal yang berkualitas dan harga terjangkau. Bahan baku lokal yang daapt digunakan harus mengandung nutrsi yang dibutuhkan oleh ikan. Bahan baku lokal yang digunakan antara lain bahan baku nabati dan hewani. Bahan baku lokal yang dapat dijadikan sebagai sumber protein nabati antara lain 
bungkil kelapa sawit, bungkil kopra, dan dedak halus sedangkan bahan baku yang dapat dijadikan sebagai sumber protein hewani antara lain keong mas, tepung anak ayam, rebon, dan tepung usus ayam [2]. Salah satu bahan pakan lokal yang dapat dimanfaatkan sebagai bahan pakan ikan lele adalah usus ayam. Usus ayam mengandung protein sebesar 53,1\%, lemak $29,2 \%$, karbohidrat 2,0\%\%, abu $4,6 \%$ [3]. Penggunaan tepung usus ayam sebagai pakan ikan sudah dilakukan antara lain pada ikan kerapu bebek [4] dan pada ikan lele dumbo $(C$. gariepinus) [5].

Kegiatan pengabdian yang dilakukan difokuskan pada pembuatan pakan ikan secara mandiri dengan memanfaatkan limbah usus ayam. Melalui kegiatan pengabdian ini diharapkan dapat mentransfer ilmu dan teknologi dari pihak akademisi kepada masyarakat terutama pembudidaya ikan sebagai khalayak sasaran.

\section{METODE PELAKSANAAN}

Kegiatan pengabdian dilaksanakan di Desa Karang Endah, Kecamatan Gelumbang, Kabupaten Muara Enim. Target dari kegiatan pengabdian ini adalah kelompok pembudidaya ikan Cah Angon serta masyarakat di sekitarnya. Kegiatan pengabdian kepada masysarakat dilakukan dengan kegiatan sosialisasi, pelatihan dan praktek pembuatan pakan serta pendampingan pemanfaatan limbah usus ayam sebagai pakan ikan lele.

\section{HASIL DAN PEMBAHASAN}

Kegiatan pengabdian dihadiri oleh Kepala Desa Karang Endah, perwakilan Dinas
Perikanan Kabupaten Muara Enim, masyrakat pembudidaya ikan di Desa Karang Endah serta tim pelaksana baik dosen dan mahasiswa Program Studi Budidaya Perairan, Universitas Sriwijaya. Kegiaatan diawali dengan sosialisai yang dilakukan dengan pemaparan materi tentang pemanfaatan limbah usus ayam sebagai pakan ikan lele, kemudian dilanjutkan dengan diskusi tanya jawab, serta praktek pembuatan pakan ikan. Setelah selesai pemaparan materi, dilakukan diskusi dan tanya jawab. Para pembudidaya antusias dalam merespon materi yang disampaikan. Hal ini ditunjkkan dengan adanya beberapa pertanyaan yang diajukan. Setelah pemaparan materi, dilanjutkan dengan kegitan praktek pembuatan pakan.

Pembuatan pakan dilakukan secara demo yaitu dilakukan oleh perwakilan tim dosen dan mahasiswa serta masyarakat. Pembuatan pakan dimulai dengan persiapan bahan pakan. Bahan pakan yang digunakan antara lain tepung usus ayam, tepung ikan, tepung kedelai, dedak halus, tapioka, minyak ikan serta vitamin mix. Bahanbahan tersebut kemudian disusun dalam formulasi pakan (Tabel 1).

Tabel 1. Formulasi pakan yang digunakan

\begin{tabular}{clc}
\hline No & Bahan Pakan & $\begin{array}{c}\text { Komposisi } \\
(\%)\end{array}$ \\
\hline 1 & Tepung Ikan & 17,8 \\
2 & Tepung Usus Ayam & 17,8 \\
3 & Tepung Kedelai & 17,8 \\
4 & Dedak Halus & 22,3 \\
5 & Tapioka & 22,3 \\
6 & Minyak Ikan & 1 \\
7 & Vitamin Mix & 1 \\
\hline & Jumlah & 100 \\
\hline & Protein $(\%)$ & 30 \\
\hline
\end{tabular}

Pemilihan bahan pakan yang digunakan berdasarkan kebutuhan nutrisi ikan lele. 
Kandungan nutrisi pakan yang sesuai dengan kebutuhan nutrisi ikan maka akan menghasilkan menghasilkan pertumbuhan ikan yang optimal [6]. Kebutuhan nutrisi meliputi protein, lemak, Do karbohidrat, vitamin dan mineral. Protein pakan Gambar 1.

yang digunakan yaitu sebesar 30\%. Hal ini sesuai dengan literatur yang menyebutkan bahwa kebutuhan protein ikan lele sebesar 25-35\% [7]. Sumber protein yang digunakan berasal dari nabati dan hewani. Sumber protein hewani yang digunakan yaitu tepung ikan dan tepung usus ayam sedangkan sumber protein nabati yang digunakan antara lain tepung kedelai. Sumber karbohidrat yang digunakan berupa dedak dan tapioka. Tapioka juga berfungsi sebagai binder (perekat) pakan. Sumber lemak dan vitamin berturut-turut berasal dari minyak ikan dan vitamin mix.

Usus ayam yang digunakan diperoleh dari pasar tradisional. Sebelum dijadikan tepung, usus ayam dibersihkan kemudian direbus lalu diperas dan dijemur. Setelah kering, usus ayam dihaluskan menggunakan blender sampai haslus menjadi tepung kemudian diayak. Begitu juga dengan tepung ikan, tepung kedelai, dedak dan tapioka, semua bahan diayak sebelum digunakan. Setelah semua bahan siap, kemudian semua bahan ditimbang sesuai formulasi pakan (Tabel 1).

Tahap selanjutnya adalah pembuatan pakan dengan cara mencampur semua bahan yang sudah ditimbang ke dalam wadah dimulai dari bahan yang paling sedikit jumlahnya. Lalu tambahkan air hangat sebanyak $4 \%$ secara perlahan hingga menjadi kalis. Setelah itu dicetak mengunakan mesin pencetak pelet dan dijemur di bawah sinar matahari. Pakan yang sudah kering kemudian disimpan dalam wadah tertutup dan terhindar dari matahari langsung. Dokumentasi kegiatan sosialisasi disajikan pada

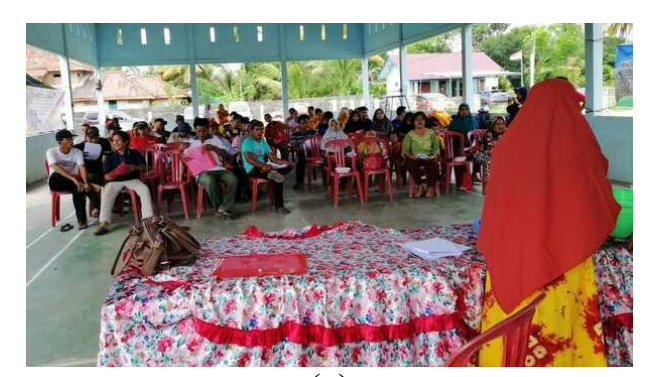

(a)

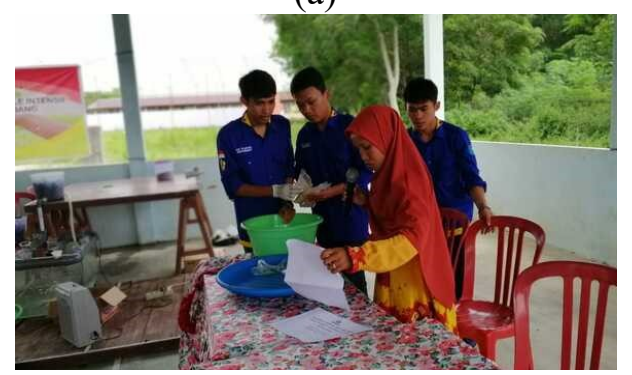

(b)

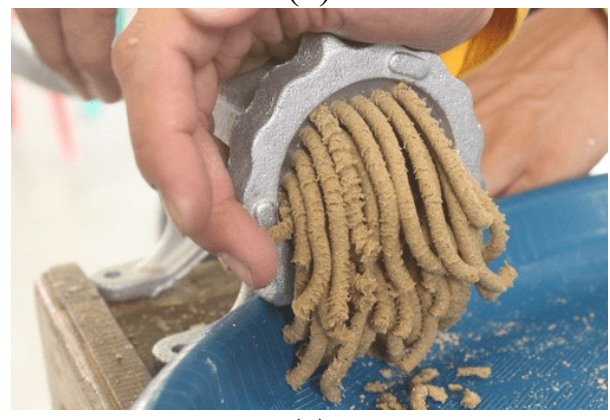

(c)

Gambar 1. Kegiatan sosialisasi

a) Penyampaian materi, b) Diskusi, c) Praktek pembuatan pakan ikan

Pendampingan dilakukan dengan penempatan mahasiswa praktek lapang dengan memanfaatkan limbah usus ayam sebagai bahan baku pakan ikan lele. Kegaiatan pendampingan dilakukan selama 30 hari. Ikan lele dipelihara dalam kolam beton kolam beton dengan ukuran $2 \times 1 \times 1,5 \mathrm{~m}^{3}$ yang ada di lokasi mitra (Gambar 2). Sebelum digunakan, kolam dibersihkan terlebih dahulu dengan cara disikat menggunakan sabun 
kemudian dibilas menggunakan air bersih.

Setelah itu, kolam diisi air setinggi $1 \mathrm{~m}$ atau sebanyak $2000 \mathrm{~L}$.

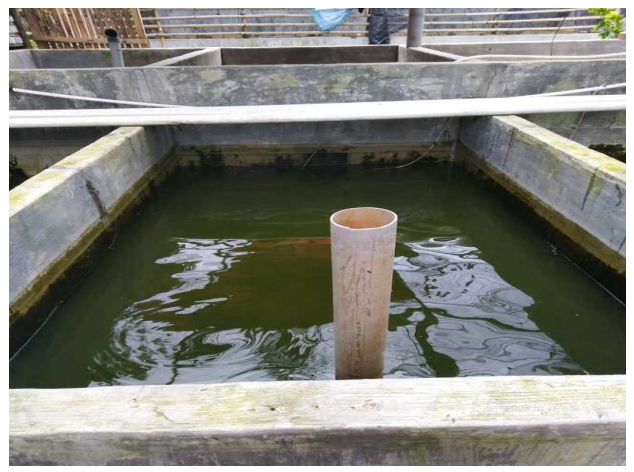

Gambar 2. Kolam pemeliharaan ikan lele

Benih ikan lele ikan lele yag digunakan berukuran 10-11 cm dengan bobot 11-12 g ditebar sebanyak 150 ekor $/ \mathrm{m}^{3}$ [8]. Sebelum ditebar ikan diaklimatisasi terlebih dahulu dan diberi pakan komersil selama 1 minggu. Setelah itu ikan dipuasakan selama 1 hari lalu ditimbang bobot dan diukur panjang tubuh ikan sebanyak 30 ekor sebagai sampel. Manajemen pemberian pakan berbahan limbah usus ayam dilakukan secara at satiation atau sekenyangnya sebanyak 3 kali sehari yaitu pada pukul 08.00, 12.00 dan 16.00 WIB.

\section{KESIMPULAN}

Kegiatan pengabdian kepada masyarakat (PKM) yang dilakukan di Desa Karang Endah, Kecamatan Gelumbang, Kabupaten Muara Enim terlaksana dengan lancar. Pembudidaya dapat membuat pakan dengan memanfaatkan limbah usus ayam dan mengaplikasikan dalam kegiatan budidaya ikan lele.

\section{UCAPAN TERIMA KASIH}

Kami ucapkan terimakasih kepada Lembaga Penelitian dan Pengabdian kepada Masyarakat
(LPPM) Universitas Sriwijaya atas dana PKM yang telah diberikan. Terima kasih juga kami ucapkan kepada Kelompok pembudidaya ikan Cah Angon serta seluruh pihak yang telah membantu jalannnya kegiatan PKM ini.

\section{REFERENSI}

[1] Arief, M., Fitriani, N., Subekti, S. 2014. Pengaruh pemberian probiotik berbeda pada pakan komersil terhadap pertumbuhan dan efisiensi pakan ikan lele sangkuriang (Clarias sp.). Jurnal Ilmiah Perikanan dan Kelautan, 6(1): 49-53

[2] Komarudin, Usman, Tangko, A.M. 2008. Persiapan dan penyusunan bahan baku lokal untuk formulasi pakan ikan. Media Akuakultur, 3(2):150-156

[3] Syahrizal, Sugihartono, M., Jasa, A., 2019. respon ikan lele dumbo (Clarias gariepinus, B) dalam wadah jaring hapa yang diberi pakan kombinasi pellet dan usus ayam. Jurnal Akuakultur Sungai dan Danau, 4(2):50-59

[4] Usman, Rachmansyah, Kamaruddin, Samuel L, Taufik A. 2006. Replacement of fish meal with poultry offal meal in diets for humpback grouper (Cromileptes altivelis) grow-out. Indonesian Aquaculture Journal, $1(1): 45-52$

[5] Yoel, B. Sundu, Tantu, F.Y., 2016. Pertumbuhan dan kecernaan protein ikan lele sumbo (Clarias gariepinus) yang diberi pakan berbasis tepung usus ayam sebagai pengganti tepung ikan. e-Jurnal Mitra Sains, 4(1):20-28

[6] Utomo, N.B.P., Susan, Setiawati, M., 2013. Peran tepung ikan dari berbagai bahan baku terhadap pertumbuhan lele sangkuriang Clarias sp. Jurnal Akuakultur Indonesia, 12(2):158-168

[7] Ghufron, M dan Kordi, H. 2010.

Budidaya Ikan Lele Dikolam Terpal. Lily Publisher: Yogyakarta.

[8] Standar Nasional Indonesia [SNI]. 2014. Pembesaran ikan lele dumbo (Clarias sp.). Badan Standarisasi Nasional Indonesia (BSNI): Jakarta. Jakarta.nal Nasional 